\author{
G.A. Yessenbayeva, F.M. Akhanov, T.Kh. Makazhanova \\ Ye.A. Buketov Karaganda State University, Kazakhstan \\ (E-mail: esenbaevagulsima@mail.ru)
}

\title{
On the calculation of rectangular plates by the trigonometric series
}

\begin{abstract}
The article is devoted to the question of applying the method of single trigonometric series to solving the plate bending problems. In this article the structure of this method is described, its main components are highlighted, the classical approach of calculating rectangular plates hinged supported on two parallel sides and with arbitrary boundary conditions on each of the other two sides is characterized. The mathematical apparatus of the method of single trigonometric series is presented in the volume necessary for calculating the plates. The detailed example of calculating a rectangular plate by the stated method is given. The article is focused mainly on students and undergraduates engaged in research work in the field of mechanics and applied mathematics.
\end{abstract}

Keywords: bending of a rectangular plate, plate deflection function, boundary conditions of plate, trigonometric series method, the solution of Levi.

Plate bending problems play an important role in construction, engineering, aviation, shipbuilding, etc. Construction and technics are the branches of activity of the industrial complex which always were, are and will remain in demand by the country's economy; therefore, issues related to the theoretical studies of such problems remain relevant and have important practical value [1].

Many analytical and numerical calculation methods are used to study the problems of plate bending $[2,3]$. An exact solution in analytical form for such problems is possible only in some particular cases of the geometrical type of the plate, the load and the conditions for its fixation on the supports, therefore, for engineering practice, approximate, but sufficiently accurate methods for solving the considered boundary value problem are of special importance.

When considering the plate bending problems, the methods of double and single trigonometric series are the most interesting because of connection with their possible numerical implementation in the Maple software package [4].

The solution in double trigonometric series (Navier's solution) is typically used for rectangular plates, freely or hinged supported around the entire contour. The solution in single trigonometric series (Levi's solution) allows to perform the calculation of a plate hinged supported on two parallel sides and with arbitrary boundary conditions on each of the other two sides.

We consider the case of a plate $0 \leq x \leq a, 0 \leq y \leq b$, in which only two opposite edges have a hinge support (for example, $x=0$ and $x=a$ ) and the other two edges have arbitrary boundary conditions.

We present the desired function of plate deflections $W(x, y)$ in the form of a single trigonometric series

$$
W(x, y)=\sum_{n=1}^{\infty} Y_{n} \sin \omega_{n} x
$$

where $\omega_{n}=\frac{n \pi}{a}, Y_{n}=Y_{n}(y)$ is an unknown function, which is chosen so that expression (1) satisfies the resolving equation of S. Germain

$$
D \Delta \Delta W=q(x, y) \text {, }
$$

and the conditions of fixing on the edges $y=0$ and $y=b$. Here $D$ is the cylindrical rigidity of the plate, $q$ is the intensity of the external distributed load, $\Delta \Delta W$ is a biharmonic operator.

The deflection and the bending moment along the hinged supported edges must be equal to zero, so the boundary conditions have the following form when $x=0$ and $x=a[5]$

$$
W=0, \quad \frac{\partial^{2} W}{\partial x^{2}}+\nu \frac{\partial^{2} W}{\partial y^{2}}=0
$$


where $\nu$ is Poisson's coefficient. It is obvious that expression (1) satisfies the boundary conditions (3), which are given on the sides $x=0, x=a$ of the plate.

We present the load function $q(x, y)$ in a form of a trigonometric series

$$
q(x, y)=\sum_{n=1}^{\infty} q_{n}(y) \sin \omega_{n} x
$$

where

$$
q_{n}(y)=\frac{2}{a} \int_{o}^{a} q(x, y) \cdot \sin \omega_{n} x d x .
$$

Substituting formulas (1) and (4) into the basic differential equation (2), we obtain

$$
\sum_{n=1}^{\infty}\left(\omega_{n}^{4} Y_{n}-2 \omega_{n}^{2} Y_{n}^{\prime \prime}+Y_{n}^{I V}\right) \sin \omega_{n} x=\frac{1}{D} \sum_{n=1}^{\infty} q_{n} \sin \omega_{n} x
$$

Obviously, the relation (6) will be satisfied if

$$
Y_{n}^{I V}-2 \omega_{n}^{2} Y_{n}^{\prime \prime}+\omega_{n}^{4} Y_{n}=\frac{q_{n}}{D}
$$

The ordinary differential equation (7) allows us to determine an unknown function $Y_{n}$ for any number $n$ of expansion. Its general solution can be written as

$$
Y_{n}(y)=A_{n} \cdot \operatorname{ch} \omega_{n} y+B_{n} \cdot \operatorname{sh} \omega_{n} y+C_{n} \cdot y \cdot \operatorname{ch} \omega_{n} y+D_{n} \cdot y \cdot \operatorname{sh} \omega_{n} y+\varphi_{n}(y),
$$

where $A_{n}, B_{n}, C_{n}, D_{n}$ are arbitrary integration constants, and $\varphi_{n}$ is a partial integral depending on the type $q_{n}$ and, therefore, on a given external load $q$.

To determine the four integration constants $A_{n}, B_{n}, C_{n}, D_{n}$, the boundary conditions defined at the edges of the plate $y=0, y=b$ are used and this boundary conditions, of course, can be different. In the general case, this leads to the solving a system of algebraic equations with respect to unknowns $A_{n}, B_{n}, C_{n}, D_{n}$.

The order of this system will increase if the load is given in the direction of the $y$-axis by a discontinuous law. For example, if the load breaks the plate in the direction of the $y$-axis into $k$ sections. For each section we will have four unknowns $A_{n}, B_{n}, C_{n}, D_{n}$, and their total number will be equal to $4 k$. Thus, to determine the integration constants, it is necessary to create a system of $4 k$ algebraic equations here, four of which will reflect the boundary conditions at the edges of the plate, and $4 k-4$ other equations will be the conjugation conditions of the $k$ sections. To overcome the noted inconvenience, the solution of equation (7) should not be represented in the form of (8), but this solution should be presented in the form of the method of initial parameters. In this case, for any law of load distribution, to find the integration constants (initial parameters), it will be necessary to solve a system of only two algebraic equations [6].

After finding the coefficients $A_{n}, B_{n}, C_{n}, D_{n}$ and determining the function $Y_{n}(y)$ by the formula (8), the plate deflections can be found by the formula (1) in the form of a series, so bending moments, torque, as well as, transverse forces will be written as

$$
\begin{aligned}
& M_{x}(x, y)=-D \sum_{n=1}^{\infty}\left(\nu Y_{n}^{\prime \prime}-\omega_{n}^{2} Y_{n}\right) \sin \omega_{n} x \\
& M_{y}(x, y)=-D \sum_{n=1}^{\infty}\left(Y_{n}^{\prime \prime}-\nu \omega_{n}^{2} Y_{n}\right) \sin \omega_{n} x \\
& M_{x y}(x, y)=-D(1-\nu) \sum_{n=1}^{\infty} \omega_{n} Y_{n}^{\prime} \cos \omega_{n} x \\
& Q_{x}(x, y)=-D \sum_{n=1}^{\infty} \omega_{n}\left(Y_{n}^{\prime \prime}-\omega_{n}^{2} Y_{n}\right) \cos \omega_{n} x \\
& Q_{y}(x, y)=-D \sum_{n=1}^{\infty}\left(Y_{n}^{\prime \prime \prime}-\omega_{n}^{2} Y_{n}^{\prime}\right) \sin \omega_{n} x
\end{aligned}
$$


Consider the case of a uniformly distributed load of the constant intensity $q=$ const. Using the formula (5), we obtain

$$
q_{n}=\left\{\begin{array}{cc}
0 ; & n=2 m, \quad m=1,2, \ldots \\
\frac{4 q}{n \pi} ; & n=2 m-1, \quad m=1,2, \ldots
\end{array}\right.
$$

Then, taking into account (10), the partial integral of equation (7) can be written as

$$
\varphi_{n}=\left\{\begin{array}{cc}
0 ; & n=2 m, \quad m=1,2, \ldots \\
\frac{4 q}{n \pi \omega_{n}^{4} D} ; & n=2 m-1, \quad m=1,2, \ldots
\end{array}\right.
$$

It can be seen from (11) that for even $n$, the homogeneous differential equation (7) has only trivial solution, so in the case of a uniformly distributed load of constant intensity the deflection function $W(x, y)$ takes the form

$$
\begin{gathered}
W(x, y)=\sum_{m=1}^{\infty}\left[A_{2 m-1} \operatorname{ch} \omega_{2 m-1} y+B_{2 m-1} \operatorname{sh} \omega_{2 m-1} y+y\left(C_{2 m-1} \operatorname{ch} \omega_{2 m-1} y+D_{2 m-1} \operatorname{sh} \omega_{2 m-1} y\right)+\right. \\
\left.+\frac{4 q}{\pi D(2 m-1) \omega_{2 m-1}^{4}}\right] \cdot \sin \omega_{2 m-1} x
\end{gathered}
$$

where the coefficients $A_{n}, B_{n}, C_{n}, D_{n}$ depend on the given boundary conditions of the plate edges $y=0$ and $y=b$.

As an example of calculating the coefficients of the plate $A_{n}, B_{n}, C_{n}, D_{n}$, we consider the case when one of the sides of the plate parallel to the $x$-axis is supported by an elastic contour, and the other side is rigidly pinched. The elastic contour may be, for example, a beam, bending under the action of pressures applied to it.

Denote by $E J$ the rigidity of the beam, then on the elastically supported edge of the plate $y=0$ the boundary conditions take the form [5]

$$
\begin{gathered}
\left.\left(\frac{\partial^{2} W}{\partial y^{2}}+\nu \frac{\partial^{2} W}{\partial x^{2}}\right)\right|_{y=0}=0 \\
\left.D\left[\frac{\partial^{3} W}{\partial y^{3}}+(2-\nu) \frac{\partial^{3} W}{\partial x^{2} \partial y}\right]\right|_{y=0}=\left.\left(E J \frac{\partial^{4} W}{\partial x^{4}}\right)\right|_{y=0} .
\end{gathered}
$$

On the rigidly pinched edge of the plate $y=b$, the boundary conditions are written as

$$
\left.W\right|_{y=b}=0,\left.\quad \frac{\partial W}{\partial y}\right|_{y=b}=0
$$

Note that from the relation

$$
\sum_{n=1}^{\infty} F_{n}(y) \sin \omega_{n} x=G(x, y)
$$

when multiplying (15) by $\sin \omega_{k} x$, integrating with respect to $x$ from 0 to $a$ and replacing $k$ by $n$, we receive

$$
F_{n}(y)=\frac{2}{a} \int_{0}^{a} G(x, y) \sin \omega_{n} x d x .
$$

From the boundary conditions (13), (14), taking into account (15), (16) we obtain that the required function $Y_{n}(y)$ must satisfy the following relations

$$
\left\{\begin{array}{l}
Y_{n}^{\prime \prime}(0)-\nu \cdot \omega_{n}^{2} \cdot Y_{n}(0)=0 \\
Y_{n}^{\prime \prime \prime}(0)-(2-\nu) \cdot \omega_{n}^{2} \cdot Y_{n}^{\prime}(0)-\frac{E J}{D} \cdot \omega_{n}^{4} \cdot Y_{n}(0)=0 \\
Y_{n}(b)=0 \\
Y_{n}^{\prime}(b)=0
\end{array}\right.
$$

From (17) and (8) we obtain a system of algebraic equations to determine the coefficients $A_{n}, B_{n}, C_{n}, D_{n}$

$$
\left\{\begin{array}{l}
(1-\nu) \cdot \omega_{n} \cdot A_{n}+2 D_{n}=f_{1}, \\
\frac{E J}{D} \cdot \omega_{n}^{2} \cdot A_{n}+(1-\nu) \cdot \omega_{n} \cdot B_{n}-(1+\nu) \cdot C_{n}=f_{2}, \\
A_{n} \cdot \operatorname{ch} \omega_{n} b+B_{n} \cdot \operatorname{sh} \omega_{n} b+C_{n} \cdot b \cdot \operatorname{ch} \omega_{n} b+D_{n} \cdot b \cdot \operatorname{sh} \omega_{n} b=f_{3}, \\
A_{n} \cdot \omega_{n} \cdot \operatorname{sh} \omega_{n} b+B_{n} \cdot \omega_{n} \cdot \operatorname{ch} \omega_{n} b+C_{n}\left(\operatorname{ch} \omega_{n} b+b \cdot \omega_{n} \cdot \operatorname{sh} \omega_{n} b\right)+D_{n}\left(\operatorname{sh} \omega_{n} b+b \cdot \omega_{n} \cdot \operatorname{ch} \omega_{n} b\right)=f_{4},
\end{array}\right.
$$


where

$$
\left\{\begin{array}{l}
f_{1}=-\frac{1}{\omega_{n}} \varphi_{n}^{\prime \prime}(0)+\nu \cdot \omega_{n} \cdot \varphi_{n}(0), \\
f_{2}=\frac{1}{\omega_{n}^{2}} \varphi_{n}^{\prime \prime \prime}(0)-(2-\nu) \cdot \varphi_{n}^{\prime}(0)-\frac{E J}{D} \omega_{n}^{2} \cdot \varphi_{n}(0), \\
f_{3}=-\varphi_{n}(b), \\
f_{4}=-\varphi_{n}^{\prime}(b) .
\end{array}\right.
$$

After transformations, the system (18), (19) takes the form

$$
\left\{\begin{array}{l}
A_{n}+\frac{2}{(1-\nu) \omega_{n}} D_{n}=g_{1}, \\
B_{n}-\frac{1+\nu}{(1-\nu) \omega_{n}} C_{n}-\frac{2 E J}{D(1-\nu)^{2}} D_{n}=g_{2}, \\
{\left[\frac{1+\nu}{(1-\nu) \omega_{n}} \operatorname{sh} \omega_{n} b+b \operatorname{ch} \omega_{n} b\right] C_{n}+\left[\frac{\tau}{D(1-\nu)^{2}} \operatorname{sh} \omega_{n} b-\frac{2}{(1-\nu) \omega_{n}} \operatorname{ch} \omega_{n} b\right] D_{n}=g_{3},} \\
{\left[\frac{2}{1-\nu} \operatorname{ch} \omega_{n} b+b \omega_{n} \operatorname{sh} \omega_{n} b\right] C_{n}+\left[\frac{\tau \omega_{n}}{D(1-\nu)^{2}} \operatorname{ch} \omega_{n} b-\frac{1+\nu}{1-\nu} \operatorname{sh} \omega_{n} b\right] D_{n}=g_{4},}
\end{array}\right.
$$

where

$$
\begin{gathered}
g_{1}=\frac{1}{(1-\nu) \omega_{n}} f_{1} ; \\
g_{2}=-\frac{E J}{D(1-\nu)^{2}} f_{1}+\frac{1}{(1-\nu) \omega_{n}} f_{2} ; \\
g_{3}=\left[\frac{E J}{D(1-\nu)^{2}} \operatorname{sh} \omega_{n} b-\frac{1}{(1-\nu) \omega_{n}} \operatorname{ch} \omega_{n} b\right] \cdot f_{1}-\frac{\operatorname{sh} \omega_{n} b}{(1-\nu) \omega_{n}} f_{2}+f_{3} ; \\
g_{4}=\left[\frac{E J \omega_{n}}{D(1-\nu)^{2}} \operatorname{ch} \omega_{n} b-\frac{1}{1-\nu} \operatorname{sh} \omega_{n} b\right] \cdot f_{1}-\frac{\operatorname{ch} \omega_{n} b}{1-\nu} f_{2}+f_{4} ; \\
\tau=2 E J+b D(1-\nu)^{2} .
\end{gathered}
$$

From the last two equations of the system (20), (21), we find the values of the coefficients $C_{n}$ and $D_{n}$ :

$$
\begin{gathered}
C_{n}=\frac{\left[\tau \omega_{n} \operatorname{ch} \omega_{n} b-D\left(1-\nu^{2}\right) \operatorname{sh} \omega_{n} b\right] g_{3}+\left[\frac{2 D}{\omega_{n}}(1-\nu) \operatorname{ch} \omega_{n} b-\tau \cdot \operatorname{sh} \omega_{n} b\right] g_{4}}{\left(b \tau \omega_{n}+\frac{4 D}{\omega_{n}}\right) \operatorname{ch}^{2} \omega_{n} b+\left[D b(1-\nu)^{2}-\tau\right] \operatorname{sh} \omega_{n} b \cdot \operatorname{ch} \omega_{n} b-\left[\frac{D}{\omega_{n}}(1+\nu)^{2}+b \tau \omega_{n}\right] s h^{2} \omega_{n} b} \\
D_{n}=\frac{D(1-\nu)\left\{-\left[2 \operatorname{ch} \omega_{n} b+b \omega_{n}(1-\nu) \operatorname{sh} \omega_{n} b\right] g_{3}+\left[\frac{1+\nu}{\omega_{n}} \operatorname{sh} \omega_{n} b+b(1-\nu) \operatorname{ch} \omega_{n} b\right] g_{4}\right\}}{\left(b \tau \omega_{n}+\frac{4 D}{\omega_{n}}\right) \operatorname{ch}^{2} \omega_{n} b+\left[D b(1-\nu)^{2}-\tau\right] \operatorname{sh} \omega_{n} b \cdot \operatorname{ch} \omega_{n} b-\left[\frac{D}{\omega_{n}}(1+\nu)^{2}+b \tau \omega_{n}\right] s h^{2} \omega_{n} b} .
\end{gathered}
$$

Using the first equations of the system (20)

$$
\begin{gathered}
A_{n}=g_{1}-\frac{2}{(1-\nu) \omega_{n}} D_{n}, \\
B_{n}=g_{2}+\frac{1+\nu}{(1-\nu) \omega_{n}} C_{n}+\frac{2 E J}{D(1-\nu)^{2}} D_{n},
\end{gathered}
$$

and taking into account (22), we obtain the values of the coefficients $A_{n}$ and $B_{n}$ in the following forms

$$
\begin{aligned}
A_{n}= & g_{1}-\frac{2}{(1-\nu) \omega_{n}} \cdot \frac{D(1-\nu)\left\{-\left[2 \operatorname{ch} \omega_{n} b+b \omega_{n}(1-\nu) \operatorname{sh} \omega_{n} b\right] g_{3}+\left[\frac{1+\nu}{\omega_{n}} \operatorname{sh} \omega_{n} b+b(1-\nu) \operatorname{ch} \omega_{n} b\right] g_{4}\right\}}{\left(b \tau \omega_{n}+\frac{4 D}{\omega_{n}}\right) \operatorname{ch}^{2} \omega_{n} b+\left[D b(1-\nu)^{2}-\tau\right] \operatorname{sh} \omega_{n} b \cdot \operatorname{ch} \omega_{n} b-\left[\frac{D}{\omega_{n}}(1+\nu)^{2}+b \tau \omega_{n}\right] s h^{2} \omega_{n} b} ; \\
B_{n}= & g_{2}+\frac{1+\nu}{(1-\nu) \omega_{n}} \cdot \frac{\left[\tau \omega_{n} \operatorname{ch} \omega_{n} b-D\left(1-\nu^{2}\right) \operatorname{sh} \omega_{n} b\right] g_{3}+\left[\frac{2 D}{\omega_{n}}(1-\nu) \operatorname{ch} \omega_{n} b-\tau \cdot \operatorname{sh} \omega_{n} b\right] g_{4}}{\left(b \tau \omega_{n}+\frac{4 D}{\omega_{n}}\right) \operatorname{ch}^{2} \omega_{n} b+\left[D b(1-\nu)^{2}-\tau\right] \operatorname{sh} \omega_{n} b \cdot \operatorname{ch} \omega_{n} b-\left[\frac{D}{\omega_{n}}(1+\nu)^{2}+b \tau \omega_{n}\right] s h^{2} \omega_{n} b}+ \\
& +\frac{2 E J}{1+\nu} \cdot \frac{-\left[2 \operatorname{ch} \omega_{n} b+b \omega_{n}(1-\nu) \operatorname{sh} \omega_{n} b\right] g_{3}+\left[\frac{1+\nu}{\omega_{n}} \operatorname{sh} \omega_{n} b+b(1-\nu) \operatorname{ch} \omega_{n} b\right] g_{4}}{\left(b \tau \omega_{n}+\frac{4 D}{\omega_{n}}\right) \operatorname{ch}^{2} \omega_{n} b+\left[D b(1-\nu)^{2}-\tau\right] \operatorname{sh} \omega_{n} b \cdot \operatorname{ch} \omega_{n} b-\left[\frac{D}{\omega_{n}}(1+\nu)^{2}+b \tau \omega_{n}\right] \operatorname{sh}^{2} \omega_{n} b} .
\end{aligned}
$$


Due to the bulkiness of formulas $(22),(23)$ for the determination of the coefficients $A_{n}, B_{n}, C_{n}, D_{n}$ in the general case, and, consequently, due to the inconvenience and complexity of further use of these formulas, it is recommended that all calculations of the constants $A_{n}, B_{n}, C_{n}, D_{n}$ are carried out for specific numerical values of the system coefficients $(20),(21)$ in each particular case with given numerical parameters.

Substitution of the found coefficients $A_{n}, B_{n}, C_{n}, D_{n}$ in (8), (9), (10) gives the function of plate deflections $W(x, y)$, bending moments and torques, as well as transverse forces in the form of trigonometric series in the case where one of the sides of the plate parallel to the $x$-axis is supported by an elastic contour, and another side is rigidly pinched.

In the case of a uniformly distributed load of constant intensity q, the deflection function has the form (12) with coefficients $(22),(23)$.

In principle, the method of single trigonometric series is more accurate than the previously considered Navier's method [6], since in this method the required function $W(x, y)$ is approximated by trigonometric functions only in one direction, and in another direction the function $W(x, y)$ is sought precisely from the differential equation (7). This can be seen from a comparison of the results obtained by the two methods for the previously considered problem of bending a square plate, hinged around the entire contour, in Table [6].

It should be noted that with one term of expansion (1) in the single trigonometric series method, not only the values of the deflection $W(x, y)$ and bending moment $M_{y}$ are significantly clarified, but also the value of bending moment of another direction $M_{x}$ are greatly improved. Note that in both of the considered methods, the convergence of the series will be higher and the accuracy will be greater, than better a given load $q(x, y)$ can be represented by expansion in trigonometric functions [6].

\title{
References
}

1 Завьялов В.Н. Основы строительной механики пластин / В.Н. Завьялов, Е.А. Мартынов, В.М. Романовский. - Омск: СибАДИ, 2012. - 116 с.

2 Аханова А.С. О расчете пластин разложением в ряд функции прогибов / А.С. Аханова, Г.А. Есенбаева, Н.К. Турсынгалиев // Вестн. Караганд. ун-та. Сер. Математика. — 2016. — №2 (82). — С. 15-22.

3 Есенбаева Г.А. О расчете прямоугольных пластин вариационным методом / Г.А. Есенбаева, А.А. Смаилова // Вестн. Караганд. ун-та. Сер. Математика. - 2016. - №2 (82). - С. 56-62.

4 Косауров А.П. Анализ и особенности методов при расчете пластин и оболочек на изгиб / А.П. Косауров, П.В. Тимофеев. - М.: Фонд «Основание», 2013. - 17 с.

5 Тимошенко С.П. Теория упругости / С.П. Тимошенко, Дж. Гудьер. - М.: Наука, 1979. - 560 с.

6 Животов А.Г. О расчете прямоугольных пластин методом тригонометрических рядов / А.Г. Животов, Г.А. Есенбаева // Вестн. Караганд. ун-та. Сер. Математика. - 2015. - №3 (79). — С. 44-49.

\section{Г.А. Есенбаева, Ф.М. Аханов, Т.Х. Макажанова}

\section{Тікбұрышты пластиналарды тригонометриялық қатарлармен есептеу туралы}

\begin{abstract}
Мақала пластиналардың иілуі туралы есептерді шешуге дара тригонометриялық қатарлар әдісін қолдану мәселесіне арналған. Осы әдіс құрылымы келтірілді, оның негізгі компоненттері көрсетілді, тікбұрышты пластиналарды есептеуге классикалық әдісті сипаттайды, екі параллель жақтары топсалы бекітілген және басқа екі жақтары кез келген шекаралық жағдаймен анықталды. Дара тригонометриялық қатарлар әдісінің математикалық аппараты пластиналарды есептеу үшін қажетті көлемде ұсынылған. Берілген әдіспен тікбұрышты пластинаны есептеудің егжей-тегжейлі мысалы келтірілген. Бұл мақала, негізінен, механика және қолданбалы математика саласындағы ғылыми-зерттеу жұмыстарымен айналысатын студенттер мен магистранттарға бағытталған.
\end{abstract}

Kiлm сөздер: тікбұрышты пластинаның иілуі, пластинаның иілу функциясы, пластинаның шекаралық шарттары, тригонометриялық қатарлар әдісі, Леви шешімі. 


\title{
Г.А. Есенбаева, Ф.М. Аханов, Т.Х. Макажанова \\ О расчете прямоугольных пластин тригонометрическими рядами
}

\begin{abstract}
Статья посвящена вопросу применения метода одинарных тригонометрических рядов к решению задач об изгибе пластин. Авторами представлена структура данного метода, выделены его основные компоненты, охарактеризован классический подход расчёта прямоугольных пластин, шарнирно опертых по двум параллельным сторонам и с произвольными граничными условиями на каждой из двух других сторон. Математический аппарат метода одинарных тригонометрических рядов представлен в необходимом для расчёта пластин объеме. Приведен подробный пример расчета прямоугольной пластины изложенным методом. Данная статья ориентирована, главным образом, на студентов и магистрантов, занимающихся научно-исследовательской работой в области механики и прикладной математики.
\end{abstract}

Ключевые слова: изгиб прямоугольной пластины, функция прогиба пластины, граничные условия пластины, метод тригонометрических рядов, решение Леви.

\section{References}

1 Zavyalov, V.N., Martynov, E.A., \& Romanovsky, V.M. (2012). Osnovy stroitelnoi mekhaniki plastin [Basics of structural mechanics of plates]. Omsk: SibADI [in Russian].

2 Akhanova, A.S., Yessenbayeva, G.A., \& Tursyngaliyev, N.K. (2016). O raschete plastin razlozheniem v riad funktsii prohibov [On the calculation of plates by the series representation of the deflection function]. Vestnik Karahandinskoho universiteta. Seriia Matematika - Bulletin of the Karaganda University. Mathematics series, 2(82), 15-22 [in Russian].

3 Yessenbayeva, G.A., \& Smailova, A.A. (2016). O raschete priamouholnykh plastin variatsionnym metodom [On the calculation of rectangular plates by the variation method]. Vestnik Karagandinskoho universiteta. Seriia Matematika - Bulletin of the Karaganda University. Mathematics series, 2(82), 56-62 [in Russian].

4 Kosaurov, A.P., \& Timofeev, P.V. (2013). Analiz i osobennosti metodov pri raschete plastin $i$ obolochek na izhib [Analysis and features of methods for calculation of plates and shells for bending]. Moscow: Fond «Osnovanie» [in Russian].

5 Timoshenko, S.P., \& Goodier, J. (1979). Teoriia upruhosti [Theory of elasticity]. Moscow: Nauka [in Russian].

6 Zhivotov, A.G., \& Yessenbayeva, G.A. (2015). O raschete priamouholnykh plastin metodom trihonometricheskikh riadov [On the calculation of rectangular plates by the method of trigonometric series]. Vestnik Karahandinskoho universiteta. Seriia Matematika - Bulletin of the Karaganda University. Mathematics series, 3(79), 44-49 [in Russian]. 